\title{
Between Poetic Voice and Silence: Hart Crane, Yvor Winters, Metapoetics and Emily Dickinson's Legacy
}

\section{ABSTRACT}

The article is a comparative study of the ways in which two American modernist poets bound by a literary and human connection, Hart Crane and Yvor Winters, dealt with Emily Dickinson's legacy in their own works. My study is an attempt to place Crane within the legacy of the American Renaissance as represented not by Walt Whitman, with whom he is customarily associated, but by Dickinson, and to examine the special place she holds in Crane's poetry and in his thinking about poetry and the world at large. Crane's poetic take on the Amherst poet is set against and complemented by his friend Yvor Winters's ambiguous relationship with Dickinson's heritage: troubled by an anxiety of influence, Winters, the poet-critic, vacillates between his reverence for the female poet and his skepticism about certain aspects of her œuvre. In the close readings of the poems in question undertaken in my study, the focus is on their metapoetic dimension. Particular emphasis is laid on the dialectics of silence, which plays a key role in both Crane's and Winters's works under discussion, as well as on the related themes of blankness and absence, poetic plenitude and perfection. Attention is also given to the problematics of death, time and timelessness. While Winters concentrates mostly on metapoetics in his exploration of the Dickinsonian tradition, Crane goes further, considering the fate of female artists and gender issues, thereby transcending poetic self-reflexiveness and addressing farther-reaching community concerns, with particular emphasis on anti-patriarchal and feminist ones.

Keywords: Hart Crane, Yvor Winters, Emily Dickinson, metapoetics, silence, gender. 
The list of poets or, more broadly speaking, writers whom the American modernist Hart Crane was interested in, inspired by or even identified with is considerable. Additionally, it is worth noting that these fascinations did not preclude him from being intimidated by at least some of them. Crane scholarship abounds in references to such authors, the household names which commonly appear on such occasions being Shakespeare and other poets and playwrights of the Elizabethan age, William Blake, Edgar Allan Poe, Walt Whitman, Ezra Pound and the imagists, T. S. Eliot, Allen Tate, Yvor Winters and, outside the boundaries of the English language, Arthur Rimbaud and the French symbolists in general. The order is, of course, chronological, and is not necessarily the order of importance. On this map of literary fascinations, idolatries, mentorships, influences and connections, Emily Dickinson occupies a special place.

It is not an overstatement to say that Crane's affinity with American Romanticism is universally acknowledged. In fact, the critical tendency to see Crane as an heir of early and mid-nineteenth-century US poetry has even come under scrutiny in recent decades. Already in 1989, Warner Berthoff chastised a fellow scholar for his "unwillingness . . to give up his own binding fiction of Hart Crane as a sort of last poet-our great post-romantic, post-symbolist, perhaps even post-poetic figure of self-willed exhaustion and defeat" (72). Closer to the present day, Brian M. Reed deplores "the common, lingering stereotype of Crane as a belated romantic" (42). Reed holds Yvor Winters and, in our time, Harold Bloom responsible for such a state of affairs (19-20). The latter's "deep, abiding interest in the U.S. romantic tradition has caused him to overemphasize the tie between Whitman and Crane" (20), and his authority and übercritic status have contributed to the setting of a key trend in Crane scholarship (19-20). However, while referring to Crane as a Whitmanian poet may have become something of a critical cliché, his indebtedness to the other half of the great poetic duo of the American Renaissance remains more problematic.

A review of the literature on Crane reveals that the poet's leading monographers tend to recognize his connection to Dickinson, but give rather limited attention to it, often restricting themselves to brief mentions. And yet, as Reed reminds us, even Bloom, writing about Crane on the eve of the twenty-first century,

both restates the link to Whitman and strangely complicates the plot. He claims that Crane's express antagonist in The Bridge, T. S. Eliot, is in fact more Whitmanian than Crane himself, which means that, if he wishes to "win autonomy," he has to look elsewhere, namely, to "Emily Dickinson as prime American ancestor.” (249) 
Strikingly enough, as John P. Wargacki observes, "[w]ith the exception of Hart Crane, no modernist American poet acknowledges the deep influence of Emily Dickinson in terms of both themes and rhetoric" (90), despite the fact that "Dickinson's substantial force upon the modernist poets, conscious or otherwise, cannot be underestimated" (90). Such is the strength of this influence, coupled with a seeming dearth of book-length studies of the subject, that it leads to somewhat paradoxical situations. For example, Lee Edelman, the author of a book on Crane which has become a reference for the poet's scholars, praises Sharon Cameron for "her brief but extraordinarily subtle comments on Crane in her study of Emily Dickinson, Lyric Time" (65). More recently, this state of affairs has showed some signs of improvement, with the publication of Michael D. Snediker's Queer Optimism: Lyric Personhood and Other Felicitous Persuasions, a four-chapter scholarly work dealing with four American poets, including Dickinson and Crane, albeit discussed separately, in one chapter each.

There are three instances of Crane referencing the Belle of Amherst in his own verse: the sonnet "To Emily Dickinson" and "Quaker Hill," Part VI of The Bridge, which not only contains an invocation to her, but is also preceded by an epigraph taken from one of her lyrics. To this could be added the mentions Dickinson receives in Crane's correspondence. The aim of the present article is to examine those direct traces of America's greatest female poet in Crane's \&uvre and the modernist poet's perception of Dickinson's legacy and her persona. I propose to do so in light of a sonnet by Crane's contemporary and, for a time, friend Yvor Winters, whose title is the same as that of the aforementioned sonnet by Crane. The underlying aim of my analysis and interpretation of the works in question is to delve into their metapoetic dimension, uncovering how Crane and Winters, who was also a recognized literary scholar and critic writing about, among others, Dickinson, perceived not only their eminent predecessor, but also their own condition as poets living during the first decades of the twentieth century. This brief study is something of an introduction and encouragement to further and, as the preceding paragraph suggests, worthwhile exploration of the connection between Dickinson and Crane, whose work I am primarily interested in as a scholar of American modernism. Its main aim is to demonstrate not only what views the two modernists of my choosing held on a major nineteenth-century poet and her poetry, but also what views they held on poetry and poets tout court.

It is worth remembering that the 1920 s, the decade during which most of Crane's adult life was played out and most of his poetry written, was also the decade which saw a revival of interest in Dickinson's oewore and the beginning of her rediscovery and critical ascension. As Betsy Erkkila 
points out, Dickinson's unorthodox form alienated her early critics, but the "volumes of poems [published in the 1890s] ... were also radical enough to make Dickinson a cultural icon among several modernists, including most notably Amy Lowell, Conrad Aiken, Hart Crane, Yvor Winters, John Crowe Ransome, and Allen Tate" (14). Clive Fisher, Crane's latest biographer, reminds us how the revised literary canon was formed: "Thus the excavations began - to continue throughout Crane's literary careeramong the forgotten monuments of nineteenth-century American fiction and poetry" (42). Fisher also observes:

The idols of Gentility-Longfellow, James Fenimore Cooper, Washington Irving and others too Anglophile for their own good-were cast out and a new pantheon constructed: the achievements of Poe, Melville, Hawthorne, Thoreau and Emily Dickinson were reassessed and over a quarter-century interval American literature acquired an altogether darker lineage. (42)

The letters Crane wrote to his friends confirm Fisher's claim that "this recreation of the past was a significant literary enterprise, and one which had profound implications for Crane's later career" (42). They also confirm Brian M. Reed's claim that "Crane venerated [Dickinson] fulsomely, without qualification" (191). Such ardent admiration was by no means selfevident. Despite Dickinson's newly gained status, “[i] t was Walt Whitman, instead, who seemed, to the poets and novelists of the 1920s, the lyrical liberator who, with his expansive lines and explosive social philosophy, had heroically slipped the yoke of European convention" (Benfey 33). Moreover, "[e]ven those [modernist] poets [such as Eliot or Pound] who leaned towards a more cryptic phrasing and a smaller canvas looked less often to Dickinson than one might suppose" (33).

Crane's correspondence betrays a fierce loyalty to his female predecessor, whom he refers to as one of several "late' enthusiasms of [his]" (473). This allegiance manifests itself in, inter alia, the belief that Dickinson's legacy set a benchmark for poets to come, is ahead of its time and as such does not lose its topicality. Consequently, an awareness of her achievement is, for Crane, a measure of how knowledgeable and sophisticated critics and readers of poetry are. In a 1925 letter to Waldo Frank, the American poet thus comments on the initial reception of White Buildings, his debut poetry collection and the only volume apart from The Bridge he published in his lifetime:

At any rate your sanguine hopes for "White Buildings" warms [sic] me. It came back from Harcourt yesterday. They couldn't make anything out of most of the poems. My "obscurity" is a mystery to me, and I cant 
[sic] help thinking that publishers and their readers have never heard the mention of Sir Thomas Davies, Donne, Baudelaire, Rimbaud, Valery [sic] or even Emily Dickinson. (411-12)

Writing to Gorham Munson three years later, Crane notes: "I still stake some claims on the pertinence of the intuitions; indeed some of Blake's poems and Emily Dickinson's seem more incontrovertible than ever since Relativity and a host of other ideologies, since evolved, have come into recognition" (585). Moreover, the fact that in his 1927-28 correspondence with Winters Crane calls Dickinson by her first name only shows that he perceives their literary connection as an intimate one. Among the "forthcoming articles in the Outlook" Crane recommends "Tate on Emily" (593). When he gives Winters feedback on "the three sonnets [the latter] sent," the poet of The Bridge states, "So I can only give you my preferences: the Emily one first, the one ending- I'm dead, I'm dead' next" (598), the former being Winters's "To Emily Dickinson," one of the poems I am concerned with in this article.

As has been mentioned earlier, Winters gave voice to his interest in Dickinson not only in his own poetry, but also in his criticism. Intriguingly enough, the latter does not seem entirely compatible with the reverence expressed in his sonnet addressed to the Amherst poet. In Winters's essays published in the 1940s and 1950s, his approbation of her oeuvre is far from unconditional. One possible and rather commonsensical explanation may be that Winters's critical writings on Dickinson postdate his poetic tribute to her by two decades or more, and as such are the fruit of years of scholarly work and the product of the kind of intellectual maturity that comes in the latter half of life. In a single word, it is a Winters equipped with a sharpened critical awareness - in both senses of the word criticalwho points out certain weaknesses of Dickinson's verse in his well-known essay "Emily Dickinson and the Limits of Judgement":

The problem of judging [Dickinson's] better poems is much of the time a subtle one. Her meter, at its worse-that is, most of the time-is a kind of stiff sing-song; her diction, at its worst, is a kind of poetic nursery jargon; and there is a remarkable continuity of manner, of a kind nearly indescribable, between her worst and her best poems. (In Defense 283)

Importantly, however, Winters is fully aware of the ambivalence which marks his attitude to Dickinson and admits that formulating a critical assessment of her legacy is doomed to become a disquieting experience:

The difficulty is this: that even in her most nearly perfect poems, even in those poems in which the defects do not intrude momentarily in 
a crudely obvious form, one is likely to feel a fine trace of her countrified eccentricity; there is nearly always a margin of ambiguity in our final estimate of even her most extraordinary work, and though the margin may appear to diminish or disappear in a given reading of a favorite poem, one feels no certainty that it will not reappear more obviously with the next reading. Her best poems, quite unlike the best poems of Ben Jonson, of George Herbert, or of Thomas Hardy, can never be isolated certainly and defensibly from her defects; yet she is a poetic genius of the highest order, and this ambiguity in one's feeling about her is profoundly disturbing. (283)

Winters wrote "To Emily Dickinson" two years before the publication of The Bridge, authored by Crane and reviewed by Winters, over which the two poets quarreled irreparably. The correspondence between them ceased with Crane's famous letter of 4 June 4 1930. Long-lost, it remained unpublished until the late 1970s, when Vivian H. Pemberton's 1978 article "Hart Crane and Yvor Winters, Rebuttal and Review: A New Crane Letter" appeared. That same year, Thomas Parkinson published his edition of the Crane-Winters epistolary exchange. In light of the fact that Winters claimed to have burned Crane's side of the correspondence (Parkinson xviii), it is striking that Winters's tribute to Dickinson opens with fire imagery. It also opens like a letter, with the salutation "Dear Emily." The structure of the poem seems to follow the epistolary mode, too. In the first of the sonnet's two stanzas, the speaker, presumably a man, focuses on himself, as if he wanted to give the recipient his news:

Dear Emily, my tears would burn your page,

But for the fire-dry line that makes them burn-

Burning my eyes, my fingers, while I turn

Singly the words that crease me heart with age.

If I could make some tortured pilgrimage

Through words or Time or the blank pain of Doom

And kneel before you as you found your tomb,

Then I might rise to face my heritage. (Winters, Collected Poems 49)

Stanza one contains only two direct addresses to Dickinson, in lines one and seven. By contrast, the second stanza revolves almost exclusively around Dickinson, while the speaker seemingly recedes into the background. The standard letter structure is thus preserved in the poem: like a traditional epistle, it describes the speaker's/author's situation before enquiring or speculating about that of the addressee. Unlike a typical letter, however, Winters's sonnet lacks a conclusion, or the poetic equivalent of closing epistolary formulas: 
Yours was an empty upland solitude

Bleached to the powder of a dying name;

The mind, lost in a word's lost certitude

That faded as the fading footsteps came

To trace an epilogue to words grown odd

In that hard argument which led to God. (49)

The most obvious first impression one has upon reading Winters's sonnet is that the page in question is one containing a Dickinsonian text. However, the Amherst poet's legacy may also have been extended to encompass the work of her successors, including Winters: "your page" may in fact be "my page," the speaker's own poetic output, inevitably influenced by Dickinson. The sonnet's opening lines associate the textual with the corporeal, with "eyes" and "fingers." While these somatic references may, of course, be read as metaphors, they nevertheless ground the creative process in the body, as well as the mind and soul. The act of writing is the act of seeing, since there can be no writing without reading, both in the literal and figurative senses: reading also means absorbing and relating to the literary heritage of past masters, seeing means being aware of the influence of the past, but also being able to see beyond it in order to create a new literary work. Writing and reading become almost manual tasks inno pun intended - the speaker's hands: "the words" are "turn[ed]," and the task is slow and painstaking, each word being dealt with individually. The physical exhaustion signaled stands for the mental and emotional exhaustion the creative process involves.

The painfulness of the process is also emphasized by the verb crease. The mention of "the words that crease [the speaker's] heart with age" opens up an interesting interpretative path. First of all, it reinforces the corporeal dimension of the creative act as presented in Winters's sonnet: the heart is pointed to as another site of literary creation. Secondly, it introduces the notion of the passage of time. The fact that Winters was in his late twenties when he wrote "To Emily Dickinson" makes the image of the aging heart seem somewhat surprising. One could, of course, counterargue that T. S. Eliot was even younger when he wrote "The Love Song of J. Alfred Prufrock," a poem which, in one of its many layers, may be read as a statement on the anguish of the midlife crisis. However, given the fact that Winters's relationship to Eliot and even to New Criticism, of which he is often believed to be an exponent, is a rather problematic one (Makaryk 495), we should not perhaps make too much of the analogy. "The Love Song" being a dramatic monologue written by an advocate of poetic impersonality, it would be far-fetched to identify Prufrock with Eliot. However, we can, I believe, identify the speaker of Winters's "To Emily 
Dickinson” with Winters himself. It was following this line of thinking that I assumed at the beginning of the present analysis that the speaker was male. We may thus conclude that the lyric "I" of Winters's sonnet is a young poet who feels the burden of time, not because he is growing old or even anticipates aging, but because he has to position himself vis-à-vis time as a realm which holds and carries the verbal legacy with which he should deal. Additionally, the fact that not only human skin, but also paper can be subjected to creasing sends the reader back to the mention of the "page," with which the sonnet opens.

A crease is a line and, as such, it echoes the "fire-dry line that makes them burn." Arguably the most mysterious phrase in the entire sonnet, it contains the lexical coinage "fire-dry" and the personal pronoun them. The referent of the latter may seem slightly problematic: the pronoun may hark back to "tears," but perhaps also to the "eyes" and "fingers" of line three. The poem's first three lines revolve around the idea of burning or being burned. The fire imagery used in the first three lines of the poem is also an example of paradoxical imagery, since the notion of burning is combined with the motif of tears. In Winters's world, tears-and thus water-have the power to burn. While it is thinkable that crying may " $[\mathrm{b}]$ urn [your] eyes" or even other body parts, that is cause a burning sensation, the idea that it could result in "burn[ing] your page" is hardly plausible. Tears can, of course, damage paper and, more importantly, destroy the text written on it by washing it out. However, destruction by fire is more dramatic and irreversible, and its suggestion seems to introduce the reference to "Doom," and thus to ultimate destruction, in stanza two.

The second line of the sonnet further complicates things by introducing the neologism fire-dry, not to be found in any dictionary. The noun-adjective combination sends us to school dilemmas, such as "Is water wet?" and "Is fire dry?", but also to a philosopher who was important to Winters: Thomas Aquinas. Encouraged by his Stanford professor William Dinsmore Briggs, the addressee, like Dickinson, of poetic tributes by Winters, the latter familiarized himself with Aquinas' thought and became an exponent of Thomism (Parkinson 137, Makaryk 494). Aquinas' theory of the elements may account for the somewhat cryptic neologism in Winters's sonnet:

The substantial forms of the elements are determined according to the primary qualities to which all other qualities are to be traced back. The primary qualities are passive or active. The passive ones are the wet and the dry; the active ones are the hot and the cold (De Generatione et coruptione [sic], II, Lect. 2). Out of these four qualities result four possible combinations of opposed qualities and, correspondingly, four 
elements: dry heat (fire), wet heat (air), wet cold (water), and dry cold (earth). Should one of these qualities take the place of another, then the element transforms itself into another. From fire (dry heat)-when the dry is changed to wet-there arises air (wet heat); from airwhen the hot is changed to cold-there arises water (wet cold); and from water-when the wet is changed to dry-there arises earth (dry cold). (Freudenthal 116)

What seems to be a Thomistic allusion made by Winters, that is the evocation of fire, which is by definition dry, is also an allusion to the fundamental or elemental nature of things. It is, moreover, an allusion to the idea of transformation, represented by the water which acquires some of the properties of fire in Winters's poem, the act of acquisition being perhaps a reference to the transmutation of fire into water via air laid out by Aquinas. The notion of transformation-or its impossibilityis also central to what constitutes the poem's essential dilemma: the way a twentieth-century poet deals with the heritage of the preceding century and that of a great predecessor, hesitating perhaps between imitation, appropriation, adaptation, rejection and resistance.

Winters identifies a factor crucial to the problem of influence: the passage of time, which seemingly creates distance between the mentor and the heir, but does not altogether obliterate the deceptive closeness the latter feels. Winters's sonnet is permeated by a sense of impossibility and of the hypothetical. Twice in the first stanza does the American poet use conditional constructions: the burning of the page would be possible if it were not for "the fire-dry line"; similarly hypothetical is the "tortured pilgrimage / Through words or Time." In addition, Winters evokes the suffering the whole process entails, bringing to mind "the blank pain of Doom." The end of the second stanza shows the speaker helpless, almost impotent, unable to "rise to face [his] heritage." Inherent in this sense of impossibility is the idea of taking back time, of reversing its passage. The hypothetical peregrination is verbal, as well as temporal and as such it inscribes itself into what is the subject of the poem, namely literary legacy. To the notion of a poetic voice Winters opposes that of blankness, which could be the unknown that separates the present from the past and the living from the dead, but which could also be read simply as the lack of expression, the silence which could signify artistic impotence, the silenced artist or the artist who is unable to speak. Moreover, the idea of burning a page in the sonnet's first line also brings to mind the idea of silencing someone, of obliterating the textual, of cutting oneself off from someone else's expression.

The motif of destruction, crucial to Winters's sonnet, is reinforced by the allusions to Judgment Day and to Dickinson's death. This brings us to the paradox at the heart of the poem: on the one hand, the speaker 
is full of reverence for his eminent predecessor; on the other, he seems to feel the urge to resist her influence, to "burn [her] page" lest it should become "[his] page." The "I" of Winters's poem is visibly in two minds about dealing with his poetic patrimony, torn between a gesture of rejection symbolized by the ultimate destruction evoked in the opening line and a gesture of compliance and submission evoked in the last line of stanza one. The sonnet's most enigmatic line is the one containing the reference to "the fire-dry line." The line is what prevents the speaker from destroying the emblematic Dickinsonian page. The process of elemental transformation, as described by Aquinas, is not retroactive in Winters's poem: fire may ultimately become water, but tears cannot fully acquire the destructive properties of fire. The line in question may have something to do with the temporal gap that separates the speaker from the poets of the past, with the passage of time which empowers giants such as Dickinson, but renders the speaker-poet powerless. "[T] he fire-dry line," or the irreversibility of the influence, is what "makes [the speaker's tears] burn," what causes his torment and his dilemmas.

Having dealt - for better or worse-with his own creative predicament, the speaker goes on to focus - seemingly, at least—on the figure of Emily Dickinson. The second part of the poem strikes the reader as more accessible than the first one, perhaps because of the apparent familiarity of both Dickinson's œeuvre and her life story. This familiarity is, however, misleading: no matter how knowledgeable we are about the Amherst poet, a certain elusiveness is inevitable. This is perhaps one of the reasons why the entire stanza revolves around the ideas of confusion and uncertainty, inherent in the images of discolouredness, invisibility, reduction and disappearance which permeate it. Dickinson's loneliness is "[b]leached" and reduced to powdery form, "certitude" is "lost" and "fade[s]," accompanied by "fading footsteps." Finally, the mention of "an epilogue to words grown odd" suggests an ending preceded by disorientation. The sense of helplessness evoked is intensified by the sonnet's conclusion, which links the poetic dilemma, with all the suffering it involves, to the metaphysical and inscribes it into the realm of infinity, since the "hard argument [turns out to lead] to God."

One may wonder about the extent to which the latter part of Winters's poem celebrates Dickinson. While the lyric pays homage to the female poet's greatness, its tone can hardly be called triumphant. Central to the last four lines are three repetitions: those of the verbs lose and fade, and of the noun word in both singular and plural form, both forms being homophones because of the use of the Saxon genitive in one case. Winters's sonnet certainly contains several biographical or mythographic allusions, and the Amherst poet's alienation - in both personal and artistic terms-is pointed 
out. However, what may be a reference to both the existence of an unmarried woman who ultimately opted for self-chosen seclusion and the lack of literary recognition which befell her in her lifetime is also an emblem of her stature. Isolation is an existential and social condition, but it may also be a measure of greatness. Dickinson's elevated position, her "upland solitude," is symbolic of her being artistically superior to others; her loneliness and the existence of the "empty" realm over which she presides result from her having no equals. Blankness, nothingness, non-existence are again given prominence in Winters's poem in a way which reveals considerable ambiguity. On the one hand, they appear to have the usual negative connotations. "[T] he powder of a dying name" is suggestive of the oblivion Dickinson might have sunk into if it had not been for Mabel Loomis Todd's and Thomas Wentworth Higginson's efforts. It also reinforces the motif of death present in the sonnet, the mention of powder bringing to mind the biblical formula "Earth to earth, ashes to ashes, dust to dust." On the other hand, the themes of absence and emptiness may connote plenitude and excellence.

Two years before he expressed his appreciation of Winters's tribute to the Lady in White, Crane had composed his own poem of the same name, using, like Winters, "the very un-Dickinsonian form of the sonnet" (Benfey 35). One of Crane's 1927 letters to Winters ends with the sentence: "I enclose a little poem written lately to 'our Emily" (506). As Parkinson states in his annotations of the correspondence between the two poets, " $\mathrm{t}]$ he poem to Emily Dickinson was to be the subject of dour comments by Winters later, but he framed the holograph copy of it by Crane and kept in his his [sic] study" (28).

Crane's sonnet "To Emily Dickinson" remains unexplored by the poet's monographers and underappreciated by those Crane critics who make mention of it. The lack of extensive scholarly discussions of the lyric makes the present analysis particularly worthwhile. "To Emily Dickinson" is one of the poems intended for publication in Key West: An Island Sheaf, a volume which Crane planned but failed to bring out in his lifetime. The sonnet also shares the fate of some of the Crane lyrics which, before their author's death, had appeared in magazines only or which were first published posthumously. Lesser-known and-for a time at least—uncollected, such works do not generally receive as much critical attention as his magnum opus, The Bridge, or the poems included in White Buildings. Samuel Hazo, an early Crane scholar, dismisses the tribute to Dickinson and "To the Cloud Juggler," another underestimated elegy by Crane, ${ }^{1}$ as "elegiac

For an extensive reading of "To the Cloud Juggler" which counters such dismissive views of the poem, see my article "Black Suns of Melancholy: Hart Crane's Treatment of the Sun Motif in the Light of Mircea Eliade's Study of Solar Cults." 
memoirs" which at best "challenge but do not surpass the excellence of some of the best short lyrics in White Buildings" (124). In a similar vein, Berthoff categorizes the two Crane elegies in question as "memorial poems ... that may not be called perfunctory but are of interest now mainly for what they show of Crane's performative resources” (53). The monographer singles out the sonnet's penultimate stanza, which "works to classify the properties of thought regulating Dickinson's deceptively small-scale achievement, [and] may be taken as demonstrating the critical and analytic intelligence that supported Crane's deeply traditional conception of poetic making" (53). A closer examination of the elegy for Dickinson reveals that such critical repudiations fall short of doing it justice.

Described as a sonnet "which hailed as a fellow visionary with similarly heroic ambition the prolific Amherst poet who published so little" (Fisher 326) or one of Crane's "encounters with the spirits of other poets" (Brunner 239), "To Emily Dickinson" may easily seem to be an instance of metapoetic spiritualism and thus risk accusations of pretentiousness. Yet, as Edward J. Brunner explains, it is mostly "an attempt to communicate with another individual," one of the "late poems [which] may be modest simply because they are Crane's realization of how little he has" (239). The lyrics in question are particularly "dismaying" because in them "he is speaking either to those who are dead or who are beyond his hearing in some other way, asleep or indifferent"(239). As a result, "he is doomed to speak from isolation" (239). It is from such a standpoint that the lyric "I" of the poem addresses Dickinson directly:

You who desired so much-in vain to ask-

Yet fed your hunger like an endless task,

Dared dignify the labor, bless the quest-

Achieved that stillness ultimately best,

Being, of all, least sought for: Emily, hear!

O sweet, dead Silencer, most suddenly clear

When singing that Eternity possessed

And plundered momently in every breast;

- Truly no flower yet withers in your hand.

The harvest you descried and understand

Needs more than wit to gather, love to bind.

Some reconcilement of remotest mind-

Leaves Ormus rubyless, and Ophir chill.

Else tears heap all within one clay-cold hill. (Crane 87) 
Crane begins his eulogy for the New England Mystic by opposing the impossibility of her aspirations, both artistic and spiritual ones, to what, at the most basic level at least, the world had to offer her in return. The female poet's desire is equated with the hunger that became her lot in metaphorical terms. As her modernist adulator sees it, the seeming futility of her efforts did not prevent Dickinson from performing her "endless task" of satisfying her hunger, from continuing her literary and transcendent pursuits, which gives rise to another opposition in the poem, indicated by the conjunction "yet." The insatiability and unfulfillment evoked in the opening lines may thus be only apparent because what mattered most to Dickinson - and what should perhaps matter most to anybody who is a true poet-may have been the creative process itself, coupled with the emotional and spiritual processes that accompany it. The real meaning of the poet's life may in fact lie in the ostensible thanklessness of the neverending poetic endeavour, gruelling on the surface but ultimately elevating and almost mystical, and not merely in how the world responds to it. In the sonnet's first quatrain, the Belle of Amherst is celebrated as the one who " $[\mathrm{d}]$ ared dignify the labor, bless the quest" and-importantly, as we shall see-“" [a] chieved that stillness ultimately best.” Paradoxically, Crane's tribute to Dickinson eulogizes greatness not by foregrounding notions such as fullness and fulfillment, but by giving prominence to a sense of lack which larger-than-life creative goals inevitably entail. Among the paucities and absences the opening stanza of Crane's poem evokes is silence, though the word itself is not actually used. Silence-the "stillness" of the stanza's last line-is presented as something positive, the result of a quest for poetic identity, a devotion to the poetic craft and the pursuit of poetic perfection.

The author subsequently emphasizes the motif of silence in his poem. In the second stanza, Dickinson is referred to as a "sweet, dead Silencer." The phrase implies that she is a representative of the past, of the poetic tradition her young heir has to face. However, final though it seems, her death is only relative, as she remains a "Silencer" in the eyes of posterity. The noun is-in the context of Crane's poem at least-polysemous, and its denotations and connotations are worth considering, for, as R. W. B. Lewis aptly remarks, "it is always a sounder policy with Crane to assume that he knew what he was doing in his selection of words" (49). On the most basic lexical level, a silencer is someone who silences someone else, in this case successive generations of poets, intimidated by Dickinson's legacy and feeling the pressure resulting from their recognition of her greatness. This meaning of the word may thus have negative connotations, suggesting the kind of impotence and helplessness that is signaled in Winters's poem. The most direct address to Dickinson in the sonnet, 
"Emily, hear!", expresses his desperation to, metaphorically speaking, make contact with his eminent predecessor and, at the same time, break the silence which plays such a significant role in the poem. Still, Crane's Dickinson is a "sweet ... Silencer," which introduces a sense of ambiguity, again sending us back to the dilemmas voiced by Winters, who addresses the poet as "Dear Emily," yet has to struggle with the burden of her artistic heritage. The speaker of Crane's poem, meanwhile, seems to believe that the intergenerational, metapoetic and, so to speak, interpoetic connection is possible and, ultimately, brings peace rather than unease. This is indicated by the phrase "Some reconcilement of remotest mind," suggestive, as Langdon Hammer notes, of "the [postmortal] mode of address Crane shares with Dickinson [which] is strangely private or elite" (163) or of the fact that "Crane saw Dickinson as a reconciler of opposites" (Benfey 35), and thus, despite the evocations of lack with which the poem opens, an agent of plenitude.

While the word silencer is not of his own coinage, neologisms are not uncommon in Crane's poetic repertoire. Consequently, one is tempted to go beyond the exact definitions of this lexeme one may find in a dictionary and to ascribe various layers of meaning to it. Although some of them may not be entirely compatible with the word's grammatical form, such a hermeneutic transgression is perhaps forgivable given Crane's penchant for solecisms. Furthermore, if one takes a closer look at the suffix -er, which may refer to somebody being an agent, but also to a person's qualities, place of origin or residence or the object of their preoccupations, one cannot be entirely sure that the poet himself did not intend to neologize by giving the word silencer additional meanings. Crane's Dickinson is not only a silencing force because she intimidates other poets; she is herself subjected to silencing by being virtually unpublished in her lifetime and unappreciated or, at best, underappreciated in the decades immediately following her death. She is, in other words, one who lived in silence, whose abode was silence, who was marked and characterized by silence, for whom silence became an attribute. Crane's explicit reference to Dickinson not being in demand, "[b]eing, of all, least sought for," is a sad constatation of her fate and early reception. It may also be a more personal and even individualistic statement on the American modernist's part, which sums up his own situation as man and poet, as well as the literary climate of the day and contemporary gauges of literary status:

Clearly, an unusually perceptive temperament was needed to find in Dickinson's work, during the 1920s, a heroism comparable to Whitman's noisier, self-celebrating "barbaric yawp." Hart Crane, who himself knew something about "starving of passion" in his father's garden, had such 
a temperament. Mulling over his own outsider status, as a homosexual amid masculinist poets like Williams and Ezra Pound, Crane had already, in his great poem "The Bridge," revealed a more vulnerable side of Whitman than the bluff caricature of many 1920s evocations. (Benfey 34-35)

It is not entirely clear, as is often the case in Crane's solecistic verse, whether the past participle of the verb seek, somewhat idiosyncratically followed by the preposition for while the preposition after would be more expectable, refers, as I have suggested in the previous paragraph, to Dickinson herself or the "stillness" or silence which is associated with her. This dual, ambiguous phrasing may be suggestive of the fact that the poet known as the Woman in White is enveloped in silence, that silence and her persona merge.

Dickinson is a "Silencer," one that makes silence, in yet another sense of the word: she is a past master of silence, one who gravitates towards silence, seen as a symbol of the poetic absolute. Such a perception of silence permeates Crane's poetry, whether it refers to Dickinson, with her love of ellipsis, blank spaces and anything that connotes muteness, or the French symbolist Stéphane Mallarmé. Ultimately, silence in poetry is akin to the music of the spheres, perfect heavenly music, superior to earthly music and inaudible to mortal ears. ${ }^{2}$ In his analysis of selected poems from the White Buildings collection, Gordon A. Tapper points out the importance of purity to Crane (13-68). What the critic refers to as "Crane's poetics of difficulty," solecistic, catachrestic and neologistic (9), is aimed at achieving linguistic purity, transcending language and approaching "a pure language of silence” (15). Such a chimera seemingly creates a contradiction, since a poet's material is language and the realm of wordlessness and soundlessness "is not a place where any poet can truly go, and remain a poet" (16), especially if one creates, as Crane does, elaborate soundscapes. For Crane, however, the two opposites are not necessarily unreconcilable:

It is as if the optative language of silence is the essentialized spirit of the verse; the sensuous aurality, its body. We are not meant to choose one over the other, just as Crane does not. We are meant to savor the disorienting effect of a style based in patterns of sound but premised on a phenomenology of silence, of purity. (16)

2 For a study of Crane's and Mallarmé's exploration of the connection between poetry and silence in the context of the concept of musica universalis, see my article "The Sound of Silence: Saint Cecilia and Celestial Music in Hart Crane and Stéphane Mallarmé.” 
Unsurprisingly, "silence as a poetic ideal recurs over and over again as an analogue for purity" (16) in Crane's ceuvre. One example is "his reverent epithet for Emily Dickinson" (16), contained in a poem which Tapper fails to analyze, but which, as I have demonstrated, equates her with silence and the process of silencing and being silenced. In poetry, the missing link between more traditional works and silence, which is, simultaneously and paradoxically, the ultimate poetic ideal and the poet's dead-end alley suggested by Tapper, is verse which is self-referential or non-referential and abstract. This is perhaps what is at the back of Crane's mind when, in the sonnet's penultimate line, he refers to Ormus and Ophir. They are, as Hammer reminds us in the notes accompanying the poem, an "island in the Strait of Hormuz, the site of an important Arab emporium for the Chinese and Indian trade in the thirteenth century" and a "[r] egion mentioned in the Old Testament as famous for its gold and other expensive commodities" (Crane 802), respectively. According to Benfey, in the poem's coda, the American modernist salutes "Dickinson's genius in the use of abstractions and exotic diction" (35). ${ }^{3}$

Similarly to Winters, Crane employs the motif of tears, with which his sonnet ends. It is combined with the motif of the "clay-cold hill," which recalls the "upland solitude" mentioned in Winters's poem. Here too the image of an elevated place may connote Dickinson's artistic superiority as well as her isolation. On a more literal plane, it may also be a reference to a burial mound, the tears being an emblem of mourning. This evocation of death dovetails with the theme of temporality inscribed into Crane's tribute to Dickinson. The Amherst poet is "most suddenly clear / When singing that Eternity possessed / And plundered momently in every breast." The connection between the nineteenth-century poet and eternity is later strengthened by the declaration: "Truly no flower yet withers in your hand," both statements, with their explicit references to body parts, sending the reader back to the corporeal imagery used in Winters's sonnet and to its emphasis on the somatic dimension of poetry. At the most basic level, Crane notes the fact that Dickinson, unappreciated by her contemporaries, was ahead of her time, a forerunner of modernist and modern poetry: born out of time, she produced poetry which has a timeless quality. Her greatness thus consists in, among other things, her having the key to timelessness, of which most human beings get only a glimpse. As always, however, Crane is unwilling to oversimplify his poetic message: unsurprisingly, stanza two evokes the complex and unobvious interplay

For an analysis of the connection between self-referentiality, non-referentiality and abstraction in Crane's poetry, see my article "Art (and) Criticism: Hart Crane and David Siqueiros." 
between time and timelessness. The adverb momently, classified in some dictionaries as an archaism, a lexical device appreciated and used by Crane,${ }^{4}$ may describe an activity which lasts for a short time, as well as one which can happen any time or which lasts all the time. In the modernist poet's vision, the boundaries between the temporal and the eternal are blurred or at least relativized. At once "possessed / And plundered," eternity, capitalized in Crane's poem in what may seem to be a gesture of reverence for Dickinson's unorthodox punctuation, which includes the overuse of capitalization, is elusive. If, as we have seen, in Crane's tribute to Dickinson, silence and blankness stand for the pure, the ideal and the spiritual, eternity plays an equally symbolic and metaliterary role. Paradoxical and ambiguous, immutable and intangible, it also becomes the locus of poetic ambiguity and open-endedness. While by no means devoid of its mystical dimension, in purely self-referential terms, it stands, being itself endless and imponderable, for a multiplicity of meanings and infinite lyric, as well as interpretative possibilities.

One respect in which Winters's sonnet dedicated to Dickinson differs from its counterpart in Crane's oenvre is that the former does not seem to take account of its addressee's sex. By contrast, in Crane's "To Emily Dickinson," America's greatest female poet is presented as not only poet, but also woman. A depiction of her holding a flower in her hand, albeit metaphorical, does, nevertheless, bring to mind several biographical, cultural and literary associations, which are perhaps worth considering. A keen gardener and amateur botanist, Dickinson transmuted her passion for flowers into textual expression in both her poetry and correspondence. She was also known for making herbaria, which at least partially prevented the plants she loved from withering in a sense that is more literal than the one evoked in Crane's poem. ${ }^{5}$ Interestingly, this was a passion Dickinson shared with Crane, whose letters, particularly those written during his Mexican period, testify to the attention he paid to flowers and the joy he found in contemplating them. Besides playing a non-negligible role in

4 Commenting on the differences between Crane's and Gerard Manley Hopkins's poetics, Brian M. Reed observes that " $\mathrm{t}$ ] he two poets also disagreed sharply over the utility of archaisms in poetry. Hopkins sternly disapproves of archaism . . whereas Crane was a self-declared 'Elizabethan fanatic'” (249).

5 For a detailed exploration of Dickinson's personal and literary relationship with flowers and gardening, see Judith Farr's monograph The Gardens of Emily Dickinson. In her monograph Emily Dickinson: Woman Poet, Paula Bennett discusses the erotic aspect of Dickinson's poetry. Interestingly, Bennett suggests an analogy between Dickinson's flowers and female genitals, exploring the homosexual dimension of the poet's use of floral imagery. Such a homoerotic reading of Dickinson's exuve places her in the same line as Crane. For an insightful queer reading of Crane's æewvre, see Thomas E. Yingling's monograph Hart Crane and the Homosexual Text: New Thresholds, New Anatomies. 
Dickinson's and Crane's lives and writings, flowers are conventionalized symbols of beauty, femininity, love and the passage of time. Associable with woman, sexuality and temporality, the floral motif in the sonnet connotes fertility, birth and death, as well as reproductive faculties, which, given the identity of the poem's addressee, are likely to be female.

As such, the motif of Dickinson's unwithering flower sends the reader back to the mention of "labor" in stanza one: though most likely to denote the creative process and the poet's painstaking and painful task, it inevitably brings to mind the other meaning of the word labor, namely "childbirth." This reinforces the somatic dimension of Crane's sonnet, which, though not as prominent as the analogical dimension of Winters's poem, is not ignorable either. Importantly, however, what may be read as a reference to female fertility and motherhood makes the reader think about Dickinson's life story, the myth surrounding her persona and the way in which the circumstances of her existence and her personal choices influenced others' perception of her as not only a woman, but also a poet, the two spheres tending to mingle unjustifiably. Her literary status and reception were tainted by patriarchal and sexist stereotypes, which Crane, a gay man and queer poet, visibly wishes to undermine in his lyric dedicated to her. As Benfey rightly points out, in stanza three, "he [Crane] answered the bloomless flower claim of Williams and Aiken" (35). What the American scholar alludes to are Conrad Aiken's and William Carlos Williams's parallel views of the Amherst poet as a sterile spinster, sexually frustrated, childless and bizarre (33-34). While Aiken refers to Dickinson as "the most perfect flower of New England Transcendentalism" (qtd. in Benfey 33), he still blames her marital status for what he sees as the failings of her poetry. Williams goes even further, presenting her as the one who "starv[ed] of passion in her father's garden" and was "[n] ever a woman: never a poet" (qtd. in Benfey 34), thereby indulging in floral and horticultural metaphors while denigrating "American women poets generally, and Dickinson in particular" (Benfey 34).

Stanza three of Crane's "To Emily Dickinson" consistently-and in accordance with the cycle of the seasons-develops the vegetal metaphor it opens with: the image of the perpetually blossoming flower is followed by that of the harvest, which represents fruition in every sense of the word. The verbs gather and bind, reference work in the field, which is physical and, as such, is in keeping with the corporeal aspect of Crane's, and, for that matter, Winters's poem. Another pair of verbs which precedes the abovementioned two, descry and understand, emphasizes the creative, intellectual and visionary capacities which make Dickinson a literary trailblazer, the present tense form of the latter verb underscoring the timelessness of her poetic ceuvre. Furthermore, it is suggested that neither "wit" nor 
"love"-incidentally, two qualities which gender stereotyping dissociates, conventionally ascribing reason to men and emotion to women-are sufficient to produce a poetic genius: someone like Dickinson combines both with yet another quality, which remains largely impenetrable and indescribable, but enables the artist to approach perfection.

When Crane wrote "To Emily Dickinson," work on The Bridge, his best-known and most ambitious work, published in 1930, was already in progress. The sixth of the epic poem's eight numbered sections, "Quaker Hill," is prefaced by two epigraphs. The first of them is a quotation from Isadora Duncan: "I see only the ideal. But no ideals have ever been successful on this earth" (Crane 64). The citation is a fragment from My Life, the celebrated dancer and choreographer's autobiography, which appeared posthumously in 1927, the year of her death and the year in which Crane composed his sonnet to Dickinson. The second epigraph is taken from Dickinson's poem XLVII. Crane uses its first two lines to introduce his own poetic text: "The gentian weaves her fringes, / The maple's loom is red" (64). The presence of the two female artists, so to speak, hovers over "Quaker Hill," references to them acting as an intertextual brace, which consists of the mottoes loco citato and a line which appears towards the end of this part of The Bridge:

So, must we from the hawk's far stemming view,

Must we descend as worm's eye to construe

Our love of all we touch, and take it to the Gate

As humbly as a guest who knows himself too late,

His news already told? Yes, while the heart is wrung,

Arise-yes, take this sheaf of dust upon your tongue!

In one last angelus lift throbbing throat-

Listen, transmuting silence with that stilly note

Of pain that Emily, that Isadora knew!

While high, from dim elm-chancels hung with dew,

That triple-noted clause of moonlight-

Yes, whip-poor-will, unhusks the heart of fright,

Breaks us and saves, yes, breaks the heart, yet yields

That patience that is armour and that shields

Love from despair-when love foresees the end-

Leaf after autumnal leaf

break off,

$$
\text { descend- descend- (Crane 65-66) }
$$

"Quaker Hill" was written in the late summer and autumn of 1929, a time of the year which, as the passage quoted above demonstrates, 
finds its reflection in the very text of Crane's lyric. It is also compatible with what constitutes the main theme of the epic poem's sixth section, which juxtaposes America's glorious past with a disenchanting present, the lofty ideals of yesteryear with early twentieth-century realities, downto-earth, materialistic and business-oriented. Dickinson's poem XLVII captures exactly the same moment: the passage of summer into autumn. The speaker observes her "departing blossoms" (Dickinson 33) before engaging in funeral rites performed in honour of the deceased season, the mourners including birds and insects:

We trust that she was willing-

We ask that we may be-

Summer-Sister-Seraph!

Let us go with thee!

In the name of the Bee-

And of the Butterfly-

And of the Breeze-Amen! (33)

Importantly in the context of the present article, Dickinson's lyric dovetails not only with the part of The Bridge for which it provides the epigraph, but also with the poem by Crane previously discussed in this article. The Dickinson work in question, as its two lines selected by the modernist with "Quaker Hill" in view illustrate, is also an example of how she translates her interest in botany into verse. Evocations of death and the seasonal cycle, accompanied by religious and metaphysical-or perhaps, in Dickinson's case, mock religious and mock metaphysical—overtones, are present in both "The Gentian weaves her fringes" and Crane's sonnet dedicated to the Amherst poet. Interestingly, the poet emphasizes the presence of the female element in her lyric. The gentian is a woman, since she "weaves her fringes" (italics mine), and weaving itself, the motif of which is reinforced in the poem by the mention of "[t] he maple's loom," is typically believed to be a female occupation. Summer, the dead season, is feminized, as is indicated by both the use of the personal pronoun she and the fact that the deceased is referred to as "Sister." Such a lexical choice, highlighted by the alliterative phrase of which it is part, implies female comradeship and solidarity, making one think of the way the word sister was employed by feminists.

In “Quaker Hill," Crane foregrounds, albeit not ostentatiously so, two outstanding, creative women, one known as the Mother of Modern Dance and the other commonly seen as the mother of modern and modernist poetry. Both may be regarded as feminists or at least protofeminists, despite Dickinson's famous refusal to officially support the women's 
rights cause and in keeping with the emancipated views on women's condition and status in society expressed in some of her poems. Both may also be associated with liberation, having freed their respective artistic disciplines from time-honoured constraints by going against conventions. Duncan was as liberated in her private life as she was in her art. Despite the lingering stereotype of an inhibited spinsterly eccentric attached to her, the infinitely more discreet Dickinson may also be considered an exemplar of inner liberation, intellectual, psychological and spiritual if not sexual or public. Famously, she never married, started a family or led a conventional social life. It is, of course, open to debate whether the circumstances of Dickinson's private life were the result of conscious personal choices or her inner psychological constitution. If we assume the former, her lifestyle may seem quite progressive by the standards of her time, her self-chosen seclusion being perhaps an emblem of modern female independence avant la lettre rather than an extreme case of outré behaviour.

What is more, the title of Part VI of The Bridge-as well as references to the Society of Friends within the section itself-encourages a reflection on the link between Quakerism and women's emancipation. Favourable to individual freedom in general, the Quakers, champions of social justice, tolerance and equality, promoted both abolitionism and women's rights, and a number of leading American feminist activists of the first wave, namely Lucretia Mott, Susan B. Anthony and Alice Paul, came from Quaker backgrounds. With these considerations in mind, the gender and profemale dimension of "Quaker Hill" must probably be seen as stronger than it seems at first glance. Additionally, gender problematics are often interconnected with queer problematics, and Crane's fascination with Isadora Duncan may be a good case in point. Not only does Crane honour a remarkable woman, but he also sees her art as relevant to dilemmas generated by his own sexual orientation. The emphasis the American dancer placed on naturalness and freedom of the body and its movements, the fact that she danced barefoot and in loose clothes, which provoked accusations of her being half-naked and, consequently, immoral, was particularly important to Crane for two reasons, as Tapper explains:

On one level, Crane's enthusiasm for Duncan echoes the reactions of the Greenwich Village radicals during the 1910s, who perceived her dancing as a symbol of artistic and social freedom and therefore embraced Duncan as a co-conspirator in their quarrel with the genteel tradition. ... Duncan's defiant celebration of the unencumbered body was [also] particularly meaningful for Crane because his perspective as a gay man sensitized him to social constraints imposed upon the body and, more specifically, to normative definitions of sexuality. (2) 
"Crane's indignation [at the audience's rejection and misunderstanding of Duncan's art] demonstrates," Tapper also observes, "that he identifies with Duncan as the cosmopolitan artist, the agent of high culture in confrontation with a philistine bourgeois public" (3).

The references to Emily Dickinson and Isadora Duncan contained in "Quaker Hill" are generally interpreted by the modernist poet's monographers along similar lines and rather briefly. They are described as part of Crane's endeavour to convey "the condition of artists in a mercantile world and to idealize those figures he considered his fellow outlaws" (Fisher 416), "[b]oth epigraphs represent[ing] the artist speaking to herself" and constituting "not so much a criticism of society as a personal meditation on futility" (Combs 157). However, what tends to be largely ignored is the gender dimension of these references. John T. Irwin hints at it when he notes that Dickinson and Duncan "represent a shift in the female archetype from being the passive object of desire to being the active subject of desire as artists ... embody[ing] ... a form of the artist's active passivity, the suffering the serious artist must endure" (124). The "patient endurance of Emily Dickinson and Isadora Duncan in 'Quaker Hill'” shows

that in elaborating the feminine ideal in The Bridge, in building the virgin on this strange shore, Crane was not simply recreating a symbol of that American ideal of the motherland's inexhaustible virginity but also creating the figure of the "motherly type" artist for whom this symbolic woman serves as muse. (124)

The gender aspect of "Quaker Hill" becomes clearer and more conspicuous when set against the two lyrical examinations of Dickinson's legacy and her persona explored in the present article. When the speaker of Crane's poem encourages the unnamed addressee, who may be none other than himself, to "[l] isten, transmuting silence with that stilly note / Of pain that Emily, that Isadora knew!", he plays out all the intricacies and nuances of silence. He also explores its complex and inevitably paradoxical relationship to poetic expression, which, as discussed earlier, are central not only to his, but also to Winters's reflection on Dickinson's literary heritage. While some exegetes of The Bridge single out the motif of pain when scrutinizing the couplet from "Quaker Hill” quoted above, associating it, inevitably, with the artist's eternal martyrdom, it seems to me that the motif of silence is the one that should be foregrounded in the first place. The first of the two lines in question is a nearly oxymoronic amalgam of sound ("Listen") and soundlessness ("silence," "stilly"), further complicated by the fact that silence is, paradoxically, to be transformed by means of "that stilly note," and thus by means of silence itself. 
While we have already seen the poetic implications of silence as identified by Crane, namely the state of being suspended between a poetic impasse and a poetic absolute, the gender implications of the phenomenon are worth noting, as well. In her seminal essay "The Laugh of the Medusa," French feminist theorist Hélène Cixous expounds her concept of écriture féminine, a kind of writing which is "female," but by no means the preserve of women, into which, it may be argued, Dickinson's unorthodox, subversive, open-ended poetics inscribes itself. "Write your self. Your body must be heard," urges Cixous, advocating the need for "woman's seizing the occasion to speak" and pointing out "how great a transgression it is for a woman to speak-even just open her mouth-in public" (880). "[E]ven if," the French critic adds, "she transgresses, her words fall almost always upon the deaf male ear" (880-81). The corporeal aspect of écriture féminine is manifested, among other things, when Cixous observes that when some women speak, they do so with their whole bodies. This interlink between the somatic, the intellectual, the creative and the textual sends us back to Crane's and Winters's reflections on the same subject, as well as the former's belief in the importance of Duncan's liberation of the body. The French theorist, meanwhile, combines reflections on corporeality with those on the ambiguousness silence unavoidably entails:

Women must write through their bodies, they must invent the impregnable language that will wreck partitions, classes, and rhetorics, regulations and codes, they must submerge, cut through, get beyond the ultimate reserve-discourse, including the one that laughs at the very idea of pronouncing the word "silence," the one that, aiming for the impossible, stops short before the word "impossible" and writes it as "the end." (886)

Anticipating the advent of a new, "speaking" femininity, Cixous celebrates, somewhat surprisingly, Dora, Sigmund Freud's aphonic patient, seeing her silence as a sign of resistance which foreshadows triumph: "You, Dora, you the indomitable, the poetic body, you are the true 'mistress' of the Signifier. Before long your efficacity will be seen at work when your speech is no longer suppressed, its point turned in against your breast, but written out over against the other" (886). It is hard not to read the theme of aphonia in "The Laugh of the Medusa" and, by extension and analogy, the dialectics of silence in Crane's poetic references to Dickinson as a statement on the erasure of women from artistic, cultural and literary history, a consequence, obviously, of their being disempowered and sidelined in social and political terms. The modernist poet's reflection on silence may also be a reflection on female voicelessness, resulting from three factors. First of all, women were reticent to speak in the metaphorical 
and public senses of the verb. When they did pluck up the courage to do so, they were either disheartened or even prevented from speaking up, both on the socio-political and artistic levels. When they did resist all forms of intimidation, their voice was ignored or underplayed. Crane's is a poetic statement on the painful void all this has created over centuries. Female artists were doubly vulnerable: because they were artists, and thus likely to be victimized and to suffer, and because they were women. The implications of this double exposure must have been particularly resonant for someone like Crane, whose predicament was also twofold, being that of an artist and of a homosexual, ${ }^{6}$ and therefore a representative of a group prone, like women, to marginalization, being treated as other and, consequently, silenced, made invisible and effectively absent.

One quality which is accentuated in both "Quaker Hill" itself and the poem by Dickinson from which the epigraph to that part of The Bridge is derived is patience. In "The Gentian weaves her fringes," the feminized summer dies after "[a] brief, but patient illness" (Dickinson 33). In the closing lines of "Quaker Hill," Crane mentions " $[\mathrm{t}]$ hat patience that is armour and that shields / Love from despair." The prominence given to this particular virtue is perhaps not coincidental in a poetic text whose gender dimension is strong. Believed to be a typically feminine trait, patience is a quality women have to develop even if they are not naturally endowed with it, because this is what society expects of them and what they need to be equipped with in a patriarchal world in which, because of their sex, they face more prohibitions and less forgiveness. As Irwin perceptively reminds us, the very etymology of the word patience connotes suffering (76), but, as an "armour . . . that shields," it also contains a promise of victory. As such, this almost proverbially female attribute, which all artists, regardless of sex and sexual orientation, need to possess in order to survive creatively, psychologically and socially, reveals itself to be as equivocal as the many facets of silence explored by both Crane and Winters in the poems discussed in the present article. Like silence, patience implies both weakness and strength, and promises both defeat and victory. Simply put, "Isadora Duncan danced, oblivious to the catcalls of her disapproving audience; Emily Dickinson wrote, indifferent to whether anyone read or not" (Brunner 225), both of them "retir[ing] to an inner world of individual excellence" (224). Art becomes a feminized, patient force, fragile, but perhaps able to oppose, in the long run and by means of

6 Langdon Hammer suggests that Crane's "To Emily Dickinson" is encoded with a homoerotic message, the mention of Ophir, the land of gold, being "a pun on the name of Emil Opffer" (Crane 802), a golden-haired Danish-born sailor who was, arguably, the love of Crane's life and the inspiration behind Voyages, Crane's cycle of six love poems. Interestingly, Opffer also happened to be Emily Dickinson's namesake. 
love, the brutal forces of capitalism, industrialism and imperialism, which Crane denounces in "Quaker Hill." Almost a century after The Bridge was published, the latter must still be seen as predominantly male and predatory, the patriarchal violators of America, the once-innocent land which was the poet's motherland.

Crane's and Winters's poetic tributes to Dickinson, which overlap, differ and complement each other, turn out to be voices in a metapoetic discussion. Its implications, contrary to what one may initially expect, transcend the realm of a poet's self-reflexive or even individual dilemmas, as exemplified largely by Winters's sonnet, and come to encompass, in Crane's vision, community issues which concern the world at large. For the two American modernists, Dickinson is a major point of reference, representing not just herself and her euvre, but poetry at large. While Crane's allegiance to the Amherst poet and his recognition of the universality of her achievement are unconditional, Winters, especially in his capacity as a critic, has reservations about the quality of her poetic output, which, however, does not prevent him from seeing her as a literary giant. Ambivalence marks not only Winters's attitude to Dickinson, but also the way he feels about literary legacy in general. Aware of the value, as well as the weight and problematic nature of Dickinson's and, for that matter, all poetic influence, Winters seems to be torn between a strong sense of his artistic heritage and a desire to resist what is revered.

Both Crane and Winters thoroughly explore the far-reaching implications of silence and its complex relationship to poetic expression, as well as the related tropes of emptiness and blankness. Both also argue that, despite their frequently negative connotations, all three may be associated with plenitude and perfection. This is also the case with Dickinson's alienation, perceived by her two modernist successors as a sign of her artistic and spiritual superiority. Crane celebrates the fact that Dickinson's larger-than-life creative aspirations and her dedication to her art were more important to her than worldly applause. Like Winters, he realizes that suffering is inextricably linked with creation, which, Crane suggests, is ultimately a source of elevation and fulfillment. The nineteenth-century poet is found to be intimidating by Crane and Winters alike, but the former appears to accept it more easily, identifying with Dickinson, the poet of silence, which plays an important role in his own poetics as an emblem of the absolute, the pure and the ideal. Crane examines the complexities of time, death and eternity, presenting the Belle of Amherst as a timeless poet. Time and death also constitute a significant part of Winters's poetic meditation on the problematics of literary legacy. In addition, the corporeal dimension of creation is pointed out by Winters and, to a lesser extent, by Crane. 
Importantly, in his poems referring to Dickinson, Crane, unlike Winters, addresses gender and women's issues, to which, as a queer poet, he is naturally more sensitive. Foregrounding the figures of Emily Dickinson and Isadora Duncan, artistic innovators and feminist icons, and using floral and vegetal imagery, Crane reflects on femininity and the condition of female artists. In doing so, he underlines the feminine and feminist dimensions of silence and the patriarchal erasure of women from social and cultural life, identifying suffering and patience, fragility, but also, somewhat paradoxically, strength, as the attributes of women and artists of either sex.

\section{WORKS CITED}

Benfey, Christopher. "Emily Dickinson and the American South." The Cambridge Companion to Emily Dickinson. Ed. Wendy Martin. Cambridge: Cambridge UP, 2002. 30-50. Print. https://doi. org/10.1017/CCOL0521806445.003

Bennett, Paula. Emily Dickinson: Woman Poet. Iowa City: U of Iowa P, 1990. Print.

Berthoff, Warner. Hart Crane: A Re-Introduction. Minneapolis: U of Minnesota P, 1989. Print.

Brunner, Edward J. Splendid Failure: Hart Crane and the Making of "The Bridge.” Urbana: U of Illinois P, 1985. Print.

Cixous, Hélène. "The Laugh of the Medusa." Signs 1.4 (1976): 875-93. Print. https://doi.org/10.1086/493306

Combs, Robert. Vision of the Voyage: Hart Crane and the Psychology of Romanticism. Memphis: Memphis State UP, 1978. Print.

Crane, Hart. Complete Poems and Selected Letters. New York: The Library of America, 2006. Print.

Dickinson, Emily. Emily Dickinson's Poems: As She Preserved Them. Ed. Cristanne Miller. N.p.: Harvard UP, 2016. Print. https://doi. org/10.4159/9780674968752

Edelman, Lee. Transmemberment of Song: Hart Crane's Anatomies of Rhetoric and Desire. Stanford: Stanford UP, 1987. Print.

Erkkila, Betsy. "The Emily Dickinson Wars.” The Cambridge Companion to Emily Dickinson. Ed. Wendy Martin. Cambridge: Cambridge UP, 2002. 11-29. Print. https://doi.org/10.1017/CCOL0521806445.002

Farr, Judith. The Gardens of Emily Dickinson. Cambridge: Harvard UP, 2004. Print.

Fisher, Clive. Hart Crane: A Life. New Haven: Yale UP, 2002. Print. https:// doi.org/10.2307/j.ctt1ww3vh2 
Freudenthal, Gideon. Atom and Individual in the Age of Nerwton: On the Genesis of the Mechanistic World View. Dordrecht: D. Reidel, 1986. Print. https://doi.org/10.1007/978-94-009-4500-5

Hammer, Langdon. Hart Crane and Allen Tate: Janus-Faced Modernism. Princeton: Princeton UP, 1993. Print.

Hazo, Samuel. Hart Crane: An Introduction and Interpretation. New York: Holt, Rinehart and Winston, 1963. Print.

Irwin, John T. Hart Crane's Poetry: "Appollinaire lived in Paris, I live in Cleveland, Obio.” Baltimore: The Johns Hopkins UP, 2011. Print.

Lewis, R. W. B. The Poetry of Hart Crane: A Critical Study. Princeton: Princeton UP, 1967. Print.

Makaryk, Irena R. Encyclopedia of Contemporary Literary Theory: Approaches, Scholars, Terms. Toronto: U of Toronto P, 1993. Print. https://doi.org/10.3138/9781442674417

Parkinson, Thomas, ed. Hart Crane and Yvor Winters: Their Literary Correspondence. Berkeley: U of California P, 1978. Print.

Piechucka, Alicja. "Art (and) Criticism: Hart Crane and David Siqueiros." Text Matters 8 (2018): 229-43. Print. https://doi.org/10.1515/texmat-2018-0014 Piechucka, Alicja. "Black Suns of Melancholy: Hart Crane's Treatment of the Sun Motif in the Light of Mircea Eliade's Study of Solar Cults." European Journal of American Studies 8.1 (Spring 2013): n.pag. Online article. https://doi.org/10.4000/ejas.9946

Piechucka, Alicja. "The Sound of Silence: Saint Cecilia and Celestial Music in Hart Crane and Stéphane Mallarmé." Polish Journal for American Studies 10 (2016): 23-36. Print.

Reed, Brian M. Hart Crane: After His Lights. Tuscaloosa: The U of Alabama P, 2006. Print.

Tapper, Gordon A. The Machine that Sings: Modernism, Hart Crane, and the Culture of the Body. New York: Routledge, 2006. Print.

Wargacki, John P. "Reduction and Negation in Emily Dickinson's 'There's a certain Slant of light' and Wallace Stevens's 'The Snow Man.” The Explicator 69.2 (2011): 90-99. Print. https://doi.org/10.1080/001449 40.2011.620542

Winters, Yvor. Collected Poems. Denver: Alan Swallow, 1952. Print.

Winters, Yvor. In Defense of Reason. London: Routledge \& Kegan, 1947. Print. Yingling, Thomas E. Hart Crane and the Homosexual Text: New Thresholds, New Anatomies. Chicago: The U of Chicago P, 1990. Print.

\section{Alicja Piechucka works in the Department of North} American Literature and Culture at the University of Lodz. She received her $\mathrm{PhD}$ in American literature from the University of Lodz in 2006. Her 
doctoral thesis was on T. S. Eliot's poetry. Her postdoctoral research focused mostly on Hart Crane's ceuvre. She obtained her habilitation in 2020. Her academic interests include American modernist poetry and contemporary American prose. Much of her research centers on comparative studies of American and French literature.

ORCID: 0000-0001-7522-7195

alicja.piechucka@uni.lodz.pl 